\title{
Creation order in sapiential theology: An ecological-evolutionary perspective on cosmological responsibility
}

\begin{tabular}{|c|c|}
\hline $\begin{array}{l}\text { Authors: } \\
\text { Ananda Geyse } \\
\text { Bernice Serfor }\end{array}$ & $\begin{array}{l}\text { r-Fouche }{ }^{1} \text { (D) } \\
\text { tein }^{1}\end{array}$ \\
\hline $\begin{array}{l}\text { Affiliations: } \\
{ }^{1} \text { Department } \\
\text { Testament Stu } \\
\text { of Theology ar } \\
\text { University of } P \\
\text { South Africa }\end{array}$ & $\begin{array}{l}\text { ff Old } \\
\text { dies, Faculty } \\
\text { d Religion, } \\
\text { retoria, }\end{array}$ \\
\hline $\begin{array}{l}\text { Research Proj } \\
\text { Registration: } \\
\text { Project Leade } \\
\text { A.B. Geyser-Fc } \\
\text { Project Numb }\end{array}$ & $\begin{array}{l}\text { ect } \\
\text { r: } \\
\text { uché } \\
\text { er: } 1258230\end{array}$ \\
\hline $\begin{array}{l}\text { Description: } \\
\text { This research } \\
\text { project 'Secon } \\
\text { Literature and } \\
\text { directed by Dr } \\
\text { Geyser-Fouch } \\
\text { of Old Testam } \\
\text { Faculty of The } \\
\text { University of } P\end{array}$ & $\begin{array}{l}\text { s part of the } \\
\text { d Temple } \\
\text { Qumran', } \\
\text { Ananda } \\
\text {, Department } \\
\text { ent Studies, } \\
\text { ology, } \\
\text { retoria. }\end{array}$ \\
\hline $\begin{array}{l}\text { Corresponding } \\
\text { Ananda Geyse } \\
\text { ananda.geyser } \\
\text { ac.za }\end{array}$ & $\begin{array}{l}\text { g author: } \\
\text { r-Fouché, } \\
\text {-fouche@up. }\end{array}$ \\
\hline $\begin{array}{l}\text { Dates: } \\
\text { Received: } 15 \mathrm{~J} \\
\text { Accepted: } 20 \mathrm{C} \\
\text { Published: } 06\end{array}$ & $\begin{array}{l}\text { une } 2018 \\
\text { Jct. } 2018 \\
\text { Feb. } 2019\end{array}$ \\
\hline $\begin{array}{l}\text { How to cite th } \\
\text { Geyser-Fouche } \\
\text { Serfontein, B., } \\
\text { 'Creation orde } \\
\text { theology: An e } \\
\text { evolutionary p } \\
\text { cosmological r } \\
\text { HTS Teologiese } \\
\text { Theological St } \\
\text { a5157. https:/ } \\
\text { 10.4102/hts.v }\end{array}$ & $\begin{array}{l}\text { is article: } \\
\text { e, A. \& } \\
2019, \\
\text { r in sapiential } \\
\text { cological- } \\
\text { erspective on } \\
\text { esponsibility', } \\
\text { e Studies/ } \\
\text { udies 75(3), } \\
\text { /doi.org/ } \\
75 i 3.5157\end{array}$ \\
\hline Read online: & \\
\hline 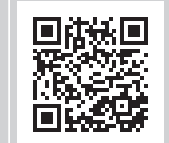 & $\begin{array}{l}\text { Scan this QR } \\
\text { code with your } \\
\text { smart phone or } \\
\text { mobile device } \\
\text { to read online. }\end{array}$ \\
\hline
\end{tabular}

This study explores humans' ecological responsibility, firstly from an evolutionary perspective and then by emphasising especially the order and creation theology in the Old Testament wisdom literature. Ultimately, these entities will be connected. The following aspects will be addressed: cosmology, ecology, evolutionary biology and order in the wisdom literature. These concepts are seen by many as exclusive towards each other, but this article will endeavour to portray them as interlocutors in dialogue with each other.

\section{Introduction ${ }^{1}$}

This world evolved in all its splendour without human help. It was the context in which the human species itself evolved, and daily provides irreplaceable nourishment for human bodies and spirits. In our day its future is in jeopardy due to human action and inaction, destructive behaviour shot through with a disastrous failure of our vaunted intelligence and virtue. (Johnson 2014:xiv)

A beautiful passage in the book of Job guides us in our theological exploration of the cosmos that ultimately leads to our ecological responsibility. The text appears when, in debate with his misguided friends, Job, the suffering man of Uz, challenges his friends to abandon their rigid assurance about how the world works and look to another source of wisdom:
Ask the beasts and they will teach you;
The birds of the air, and they will tell you;
Ask the plants of the earth and they will teach you;
And the fish of the sea and they will declare to you.
Who among these does not know
That the hand of the Lord has done this?
In his hand is the life of every living thing,
And the breath of every human being. (Job 12:7-10)

If you interrogate the flora and fauna of land, air and sea, the text suggests, their response will lead your mind and heart to the living God, generous source and sustaining power of their life (Johnson 2014:1). One of the main themes in wisdom literature is cosmological order. This study will scrutinise various perspectives on the theme 'Order in Creation' within Old Testament wisdom literature in an attempt to perceive ecological responsibility from an evolutionary perspective.

The Earth is currently caught in an ecological crisis as a result of negligence and exploitation by humanity (Caldicott 2009; Goudie 2013; Johnson 2014; Spangenberg 2014), and the ecological responsibility of human beings is regarded as very important. Ecology is traditionally a part of biology that deals with the relationship between living organisms and their environment and the aftereffects of this relationship on the whole of life, and living as we know it (Oberholzer 1989:2). The disturbance of the order of creation causes an ecological problem. Ecology will be discussed as a science; ecological responsibility of the person will be described and biblical instructions on ecology will be explored.

\footnotetext{
1.1 hereby want to honour the contribution of Eben Scheffler for always being able and willing to intertwine different disciplines. I pay tribute to him for his sharp brain and ability to accomplish, understand and discuss diverse fields. Eben Scheffler is also known for his resentment of injustice and his commitment to making a better world of this one. Therefore this study is an attempt to honour Eben Scheffler not only by means of an interdisciplinary approach but also because it focuses on injustices against nature and our Scheffler not only by means of an in
responsibility to make a difference.
}

Copyright: (C) 2019. The Authors. Licensee: AOSIS. This work is licensed under the Creative Commons Attribution License.

Note: The collection entitled 'Eben Scheffler Festschrift', sub-edited by Jurie H. le Roux (University of Pretoria) and Christo Lombaard (University of South Africa). 
Edwards (1999) gives the following statement with regard to evolution:

The evolutionary view of reality constitutes such a new context, one which is radically different from the contexts in which biblical, patristic, medieval, and reformation theologies were developed. A Theology of God for today must attempt to be faithful to the insights of the 'good news of God' from the context of an evolutionary view of the world. It must ask: How can we talk meaningfully of the Christian God in an evolutionary world? (p. 3)

An attempt to answer this question involves a 'theology of nature' and a reformulation of theology in the light of modern scientific knowledge. The answer seems to point to creation, the order of creation and an underlying wisdom that forms the basis of all. Gottwald (1985:564) believes that the dominant theme of the wisdom literature is the theme of how to adapt your life to the fundamental order of the world and how to handle it when the expected order 'fails'. God's wisdom, in the sapiential corpus of literature, is considered as the divine capacity to design, form and order creation (cf. Perdue 1994:326). Divine wisdom is closely related with the power to create and sustain the cosmos and guide providentially both individual lives and human history (Job 9:4; 12:12-16; 38:36-37; Ps 104:24; Pr 3:19; Is 33:5-6; 40:12-31; Jr 10:12; 51:15).

The focus of this article is to perceive the ecological responsibility of human beings from an evolutionary perspective. With special emphasis on order and creation theology from the Old Testament wisdom literature, this study endeavours to connect these two entities with each other. The following aspects will also be discussed: cosmology, ecology, evolutionary biology and order in the wisdom literature. These concepts are seen by many as exclusive towards each other, but in this study they will be portrayed as interlocutors in dialogue with each other. This endeavour will begin by exploring creation order in the wisdom literature. Evolution as a harmonious way to create with order will then be discussed. The dialogue between science and theology forms an integral part of this discussion. Lastly, our ecological responsibility as compulsorily ethics for wisdom will be the focus.

\section{Creation order - wisdom literature}

Murphy (1985:3) refers to Zimmerli (1964), who categorised wisdom theology as creation theology, on the basis of Genesis 1:28. Perdue (1994:25) refers to Westermann (1978) saying that: ' $\ldots$ blessing incorporates the divine power that preserves and enhances life and undergirds the continuing order of creation'.

Perdue (1994:56) emphasises that the sages did not believe that God is directly knowledgeable through their senses, but that he is recognised trough the revelation of creation, the traditions of the past and (for someone like Job) also through religious experience. They believed that creation discloses a touch of the nature and activity of God. Perdue (1994:44-45) says that the ancient Near Eastern traditions of creation and wisdom were embraced by Israel and they made it their own. Therefore, creation and wisdom is an honest expression of Israel's faith as they met the Lord in the created world.

Before we go further into wisdom literature, it seems necessary to pause for a moment at the creation narrative and a few perspectives on how it can be understood.

\section{Creation}

Von Rad (1972:48) says in his commentary on Genesis that if one considers Genesis 1:1-2 or 1-3 as a syntactical unit, then the chaos stands logically and temporally before creation. He also warns that one must take into consideration that this narrative includes concepts that lie beyond human imagination and that they derive out of a covenantal relation of Israel before God. Von Rad (1972:48) discerns two aspects that he considers to be relevant in the creation narrative. Firstly, in the freedom of God's will, God creatively established for 'heaven and earth' (absolutely everything) a beginning of its subsequent existence. Secondly, creation cannot be sufficiently considered without taking into account the notion of chaos.

\section{Von Rad (1972) emphasises how:}

... sharply little Israel demarcated herself from an apparently overpowering environment of cosmological and theogonic myths ... the subject is not a primeval mystery of procreation from which the divinity arose, nor of a 'creative' struggle of mythical personified powers from which the cosmos arose, but rather the one who is neither warrior nor procreator, who alone is worthy of the predicate Creator. (p. 49)

There was always the fear that creation would sink into the gorge of the formless and that chaos implied a threat to everything created (cf. Von Rad 1972:51).

Tension between human and non-human creatures is evident in a variety of narratives: (1) in some texts, all stand before God in the same way (Gn 9:9-10); (2) humans are treated as superior, as the ones who order, rule and care for (Gn 1:25-30, 2:15); (3) other texts are highly anthropocentric (Gn 11:1-9). According to Brueggemann (1982:11-12), this tension can only be 'dissolved' when every text is understood within the tradition it was employed as well as in the context of the issue involved. Any philosophical and political issues of meaning and power are subordinated to the essential issue of the relation between creator and creation. Two overriding theological affirmations are discerned by Brueggemann (1982:13): 'First, the creator has a purpose and a will for creation' and he continuously addresses the creation; secondly, creation (which 'only exists because of and for the purpose of the creator') has freedom to respond to the creator in several means. Brueggemann (1982:13) says that it creates 'dramatic tensions: the faithful, anguished, respectful purpose of the creator and creation's mixed response' of submissive respect and reluctance. 
According to Arnold (2009:29), the first chapter in Genesis describes the beginning of the universe, the beginning of time and space, or put simply, the beginning of everything except God, who has no beginning'. Creation is standing between eternity and history; therefore creation cannot be described as history because creation is the presupposition of history. Chaos preceded creation and this chaos was not created by God. In this line of thought, creation was thus an action of ordering and not a creation from nothing to something (cf. Van Selms 1967:19). Van Selms (1967:62) discusses the relation between the two creation narratives, which seem at first glance not to have anything in common. Both narratives recognise no other origin of the world than the sovereign creation act of the one God, and the theology of both chapters is the same.

Brueggeman's summary can be used to summarise the concept of creation. Brueggemann (2008) refers to Israel's testimony of $\mathrm{YHWH}$ as the God who can create and recreate in purposeful fashion:

Creation is not ex nihilo; it is rather the imposition of life-serving order on the pre-existent mass of chaos ... creation is an ongoing process, made necessary by the resilient power of chaos that must repeatedly be rebuked and swept back ... the work of creation is to order and to infuse blessing into creation so that, by the gift of God, the force of life is intrinsic to creation itself. (p. 159)

\section{Wisdom and world order}

The wisdom tradition stands apart from the rest of the Old Testament as having a unique worldview regarding God as creator, a rich tradition of observation of the natural world and of the interaction of human beings with both (cf. Dell 2010:57). Interest in including wisdom literature in the environmental debate has increased during the last few decades in the work of Deane-Drummond (2000, 2004, 2006, 2008), Habel (2003), Brown (1999) and McKibben (2005), to name a few. Dell (2010:57) mentions that wisdom has been regarded as: '... very much "life from the human side" in contrast to divine revelation'. Von Rad (1965:418) referred to this notion as Israel's wisdom, which they derived from experience.

Perdue (1994:23) also mentions Second Isaiah and emphasises the fact that creation theology did not receive a prominent place in the faith of Israel before the exilic era. Perdue (1994:23) states that according to Von Rad: '... creation did not achieve a central and normative role as an independent tradition of faith, save in wisdom literature'. Alternatively, creation functioned as a prologue to salvation history. The concept of world order has been discussed by several scholars. Perdue (1994:38) refers to Schmidt's systematic analysis of the major spheres in Ancient Near Eastern thought, where especially the royal tradition embraced all other spheres. 'In Egypt, where a more pronounced doctrine of order was developed, the creator was believed to have brought mảat into existence to replace chaos'. He was the lord of máat, and máat was his divine daughter. The king, as the son and devotee of $\mathrm{Re}$, was responsible for the order of creation and human society. Wisdom was the feature that gave the king the ability to rule in an orderly and beneficial manner. In the Ancient Near East (ANE) it was believed that wise acts led to both world and social order. Schmid (Loader 2014:22-23; cf. Perdue 1994:38) recognised that a similar, though less pronounced, world order developed in the Mesopotamian cultures. Still, he believes that it was too fragmentary, and he says that the Hebrew term for 'order' (mostly translated as 'justice') is expressed in the root צדק. צchmid distinguishes between צדק, the right order, and צדקה the correct action according to the order (Loader 2014:23; cf. also Perdue 1994:39). Perdue (1994:39) refers to the fact that Horst Dietrich Preuss (1970, 1987) also recognised wisdom theology as 'thoughts about order' (Ordnungsdenken). These order-thoughts arouse through observation, experience and tradition and form the core of retribution theology.

Perdue draws attention to the fact that this theology led to a crisis in wisdom thoughts. Collective experience proved that moral order was not entirely and indisputably functioning in the world. More and more emphasis was placed on the freedom of God, and with literature like Job and Qoheleth wisdom transformed into 'fear of God' (cf. Perdue 1994:39). Hans-Jürgen Hermisson (1968) also approached wisdom theology through cosmology. According to him, the principle of order is not a sapiential constitutive, but it precedes wisdom. Order is a basic category found in all domains of life, including wisdom (Loader 2014:23; cf. also Perdue 1994:39).

Since its earliest stages, wisdom has been considered as a teaching based on the expression 'fear of God' (יראת יהוה). This expression points both to pious worship and the faithful affirmation that God is the creator and sustainer of life (cf. Perdue 1994:46). Wisdom also consists of a social or communal character that is prominent throughout the teachings of the sages. Consequently, the wisdom tradition should not be considered as being fundamentally individualistic. Perdue (1994:46) asserts that creation theology in its anthropological as well as cosmological expressions is assumed to form the foundation for the entire sapiential tradition. This implies that fundamental themes throughout the wisdom corpus are the affirmation of the providence of God, the divine gift of life, the order of cosmos, the nurturing of human beings throughout life and the goal of living in harmony with creation.

Biblical wisdom literature, Loader (2014:28) notes, especially as expressed in the adages of the Book of Proverbs, seems to be a 'prima facie case for the religious, if not theological, conviction that truth is perceptible by the natural faculties inherent to the human condition'. Together with Loader (2014:28) this study asks if it is possible to offer a theological argument that would contribute to a theology in which a natural awareness of God is accommodated. ${ }^{2}$ Is it possible to

2.Loader (2014:28) is referring to the notion of natural theology. There is, however, some controversy regarding the usage of the term 'natural theology'. Natural theology can be argued as the reflection on God without the aid of supernatural revelation, in other words, specific rational thought on the basis of a general innate awareness, whereas natural religion, according to Loader, refers to people having a awareness, whereas natural religion, according to Loader, refers to people having a
natural awareness of God, which makes it a natural knowledge of God. Natural theology, however, requires an additional intellectual effort (Loader 2014:28). 
offer such an argument working from biblical literature? If so, sapiential literature has a major theological contribution and relevance in this regard.

Several biblical scholars (e.g. Barr 1993; Steitert 1990) argue that natural theology does not deny revelation and rather coexists with it. However, Loader (2014:30) asks whether natural theology and revelation are really two different things existing side by side in mutual support or whether they are not perhaps different expressions of the same thing. Loader (2014:30) points to the great Israelite traditions of God's saving acts in history that are glaringly missing from the wisdom books: 'The manifestations of divine revelation to humans determine the face of the Old Testament in general, but they are absent in the adages of wisdom'. Therefore, when wisdom is measured against the rest of the Old Testament, there is at least a shortfall of revelation. In explaining his argument, Loader (2014:30) refers to the Book of Proverbs. In the opening of the book, wisdom is aligned to faith, or Fear of the Lord (Pr 1:7). It is possible that these religious elements are the result of the natural human capacity to know God, but it could also be that they express a conviction implied throughout the other sayings where religious terminology is not used (cf. Loader 2014:30). It might be the case that all the adages similarly show how a life ought to be if it is to be 'good' or 'right' that is, if it is to fit in with the right order of things. If so, Loader (2014:30) argues, ' ... this order of things presents itself from the plain logic of the adages themselves, and is not derived from a grand scheme supposing that Israel took over a ma'at concept from Egypt as the abstract matrix from which to develop a proverbial literature'. In the context of Israel, that order can only be created from order, which implies the Creator. This perspective may entail that the inner logic of the proverbs themselves implies that God's creation is the source of knowing what God intended to be right, good or fitting (Loader 2014:30). Ultimately, a 'deficiency' of the revelation concept in wisdom literature will allow an appreciation of natural theology in the Bible and therefore requires a rethinking of the concept of revelation (cf. Loader 2014:30).

In the wisdom literature and the Old Testament at large we find a natural awareness of the divine. Loader (2014:30-38) discusses some examples of these occurrences. The deedconsequence nexus is also a possible affirmation of the theme of natural theology, and this notion works on the principle of a network of inherent relationships - that is, an order, an immanent system to which humans and animals, as well as God, are committed. Following Barr (1993:6) the basis of revelation is 'anterior knowledge'. However, this anterior knowledge is not just knowledge of dangerous elements but 'awareness of reality, of the world and its regularities, of animals and their ways, of humans and their life patterns, that is, of the order of Creation' (Barr 1993:6; cf. Loader 2014:38). This anterior awareness is also an awareness of God, because God is the Creator. Consequently, the phenomenon of revelation may be called 'deficient' in as far as it does not appear, as Loader (2014:38) articulates it, in the form of normally labelled 'revelation'. Loader (2014) explains:

Whereas 'ordinary' revelation works according to the scheme hear > Yahweh, the 'deficient' one requires its deficiency to be made up for according to a much more complex process: observation/experience $>$ interrelationships $>$ order $>$ creation $>$ Creator > Yahweh. (p. 39)

Both forms of revelation are needed in a balanced theology, and in both knowledge or awareness of God and God's will is imparted from God to humans. The Book of Proverbs is filled with demonstrations that knowledge of the natural order of phenomena is relevant for a sapiential shaping of life. ${ }^{3}$ There is an order prevailing in nature, the human mind and the handling of agriculture, industry, politics, society and culture. The cosmic order is thoroughly an Israelite notion and forms the groundwork for decisions, the organisation of life and the running of its institutions. Therefore, the experience of a fundamental order establishes the conventional position for Israelite wisdom (cf. Loader 2014:45). Should there be such a conventional order according to which the whole of reality is organised, then, as argued by Loader (2014:46), there is ipso facto a nexus of deed and consequence, whether this is seen as an automatic and immanent given or as retribution practised by God.

The emphasis on cosmology as central to wisdom theology offers an essential corrective to reading traditional wisdom through a primarily human lens. Throughout history, the affirmation of a cosmic order seems to be vital to the world view of the wisdom. Following this tradition, God is the creator of all and God continues to sustain the order of reality. Consequently, God not only makes life in its various manifestations possible but also vital and blessed. An example of this is Proverbs 3:19-20, which emphasises that the traditional way of life that leads to life, honour, riches and well-being is grounded in the structures of the cosmos itself. In light of this it can be argued that God uses wisdom in creating and ordering the world and in governing its lifeproducing activities (cf. Ps 104:24; 136:5; Jr 10:02; 51:15) (see Perdue 2014:82). Two verbs of divine creation, יסד (Is 24:18; 48:13; 51:13; Am 9:6; Zch 12:1; cf. Pr 8:29) כון (Job 28:25, 27; Ps. 93:1, 119:90; Pr 24:3; cf. Pr 8:27), are derived from the metaphor of God as the architect or builder who lays the stable foundations of a building before the columns and walls (Job 38:4-7; Ps 104:5) are erected. In this image of the divine builder or architect, wisdom is the skill, plan and knowledge used by God to secure order in the cosmos. Consequently, divine wisdom continues to offer stability to the ongoing cosmic order.

However, certain complications arise when cosmology is exclusively understood through the lens of order. Too much stress on order could result in an understanding of wisdom as a legalistic tradition in which retribution operates automatically. Such an understanding would deny God the

3.Loader (2014:39-45) offers a detailed exposition of the specific proverbs that points to this notion. 
freedom to act or not act according to divine will, justice or grace, and the sage's recognition of the eventualities of life would have no actual meaning. Nevertheless, sages time and again admitted to serious restrictions to their understanding, a confession that yielded to the reality of both divine mystery and chaos (cf. Perdue 1994:47).

\section{Wisdom, ecology and God}

Dell (2010:58) draws attention to what she calls three 'essential ecological principles' that are applicable in an evaluation of biblical texts. The first principle is with regard to the complex interrelated processes of nature and the interaction of humans with those processes and with each other. Interaction with the divine can be added as the third strand of any theologically orientated evaluation (Dell 2010:59). The second principle is concerned with the wellbeing and flourishing of all human and non-human life in both its richness and diversity. Under this heading we can include ideas about the essential goodness of creation (cf. Gn 1) and the awe at the sheer wonder of the created world (cf. Ps 104). The last principle is that of the sustaining of life. Here Dell (2010:59) points to the fact that it is often forgotten that the picture of God as creator in the Old Testament is also in essence that of a sustainer. Essentially God is the creator of the natural world and not part of nature itself. These three ecological principles assist us by providing a nuanced framework through which to look at central texts from the wisdom tradition that might inform an ecological hermeneutic in a positive way (cf. Dell 2010:59).

The first principle of 'interaction' is evident in the wisdom literature in the sheer use of nature imagery and interest in the natural world that is revealed there. In Proverbs, for example, human life is over and again illuminated by a pithy proverb, likening some aspect of human character to the natural world (cf. Pr 25:23; 6:6; 11:28; 15:17, 19). God's interaction is portrayed by the fact that God is behind the scenes, directing action, presupposed even if not specifically mentioned. In a certain way the approach in Proverbs is anthropocentric, because the sages are attempting to shed light on human character and yet at the same time they are telling something profound about their detailed observation of the non-human world around them, a world with which they interact every day. This, and other techniques, used by the sages, are about perceiving and imposing order on the world in order for human behaviour to be understood as part of a wider order that links the natural world and the divine realm (cf. Dell 2010:60; Pr 25:14). Consequently, human beings should orientate their lives in light of this understanding. Similar techniques are evident in Job (e.g. Job 3:1-10; 9:25-26; 36:26-33; 37-41) and Ecclesiastes (e.g. Ec $1: 4-9 ; 7: 6-7 ; 10: 1-2)$.

The second principle of the flourishing of life offers us a sense of the awe we should have when we consider the created world and the God who first created it and now sustains it (cf. Dell 2010:63). This notion involves ideas of the essential goodness of God's intention for the world and all its creatures (cf. Gn 1). The proverbs have an important presupposition that life is essentially good, for example, Proverbs 16:20. A sense of awe at the created world is also found in Job 28. God is responsible for creating and sustaining the wonders of the Earth and therefore human beings should stand in awe and praise God for all its grandeur. This also calls humans to the responsibility of preserving the Earth and all its wonders, which also links with the third principle.

This last principle, according to Dell (2010:66), is the notion of the sustaining of life, which is a process initiated by God but that should be continued by God's creatures. Our human duty of care is addressed here. Key texts in this regard are Job 38-39 and Proverbs 8. In Proverbs 8, Wisdom initially seems to relate to human beings - their well-being depends upon hearing her call and she represents justice and knowledge (cf. Dell 2010:67). In Job 28, Wisdom is beyond human knowledge (see also Ec 1:17; 3:11; 6:12; 7:13-20; 8:17; 10:14; 11:5). However, in Proverbs 8, Wisdom, in female façade, is on offer to humans if they are willing to take her hand and embrace her. Following Dell (2010:67), wisdom forms a bridge between the work of God and the delight that is taken in 'his inhabited world ... and the human race' (v. 31). Here we encounter a profound image of the dialectic interaction between creator and created that is at the very centre of the wisdom worldview.

One could ask if we can take any practical guidelines from the rich images that the wisdom literature offers. Indeed we can, and the sense of interaction with nature and with God is central in such a perspective. This aspect will be highlighted again in the section on ecological responsibility.

\section{Evolution}

Some theologians have taken a negative position against Darwinian thoughts; other have seen evolution as the way in which God continuously creates. This involves a conversation or conflict between science and theology. Van Heerden (2014:vii) says that in the dialogue between theology and science, in this case creation and evolution, the hope exists that Christians will develop an appreciation for the fact that science is no threat to the truth of the Bible. Van Heerden (2014) further argues:

We have here but two sides of the same story: Science tells us about the greatness of our God while Scripture informs us on how we meet that God and get to know him as our personal Father. (p. viii)

In any discussion about evolution it is in order to include a very basic account of Darwin's theory about evolution and natural selection. ${ }^{4}$ According to Haught (2008:2), 'Darwin

4.This is just a very short description of Darwin's initial idea and theory. There is an expansive body of research and theory that is insufficiently captured under the two headings 'Darwinian' and 'neo-Darwinian'. In basic neo-Darwinian theory, natural headings "Darwinian" and "neo-Darwinian'. In basic neo-Darwinian theory, natura selection and sexual selection are prioritised as the main factors in evolutionary change and the emergence of adaptations. Nowadays significant research is conducted in gaining a more comprehensive understanding of evolutionary processes, and our best understanding of evolutionary processes is called the 'extended evolutionary synthesis' : a range of different processes, beyond just natural selection, that are central in explaining why and how all living things evolved. The work of anthropologist Agustín Fuentes (2017) is of great importance in this regard. 
claimed that all forms of life descend from a common ancestor and that the wide array of living species can be accounted for by a process he called natural selection'. Members of any given species will, by sheer accident, differ from one another. From the ensuing variety, nature will consequently, 'select' only the 'fit', those best 'adapted' to their environmental circumstances, to survive and bear offspring (Haught 2008:2). This means that over huge periods of time, selection of minute favourable changes in adaptability will bring about endless new and distinct forms of life, eventually including human beings.

Darwin influenced our understanding of almost everything related to theology, and evolutionary theory is of immense worth to Christian theology (cf. Haught 2010:xv). Evolution, according to Haught (2010):

\begin{abstract}
... allows us to realize that human beings are invited to participate in the great work of creation. If we fail to keep this evolutionary perspective alive, our sense of ethical obligation and for the Christian, the following of Christ - is in danger of being reduced to blind obedience to arbitrary imperatives and divine commands, or perhaps simply to seeking a reward in the hereafter. In that case, ethical life becomes ... a matter of 'killing time,' and redemption becomes a matter of 'harvesting souls' from a pointless universe. After Darwin, Christian theology can do better than this. Even though Darwin himself seemed oblivious to the potential his discoveries have to stimulate theological, spiritual and ethical renewal, his theory of evolution is a great gift to Christian theology and spirituality as they seek to interpret Jesus' revolutionary understanding of God for our own age and future generations. (p. 148)
\end{abstract}

The revolutionary and ragged vision of life provided by evolutionary biology has to be taken into account in any realistic theological understanding of God, the natural world, human identity, morality, sin, death, redemption and the meaning of life (cf. Haught 2010:xv). The question is not how to justify evolutionary biological views of creation in a theological discussion but how to justify why it should be excluded.

\section{Science and religion: Conflict or conversation - Duet or Duel ${ }^{5}$}

In light of the dialogue between science and theology, one should bear in mind that both science and theology are human endeavours. Consequently both disciplines are practised with an abundance of methods, topics, interests and goals, which give rise to an entire landscape of nuanced and unnuanced positions where they have intersected over the centuries (cf. Johnson 2014:7). With regard to the science and religion dialogue, Pannenberg (1993) is of the following opinion:

If the God of the Bible is the creator of the universe, then it is not possible to understand fully or even appropriately the process of nature without any reference to God. If, on the contrary, nature can be appropriately understood without reference to the God of the Bible, then that God cannot be the creator of the universe, and consequently he cannot be truly God ... (p. 2)

5.'Duet or Duel' is obtained from the title of Van Huysteen's book (1998).
Contemporary cosmology includes an assortment of scientific disciplines and consequently addresses a wide range of unresolved fundamental issues relating to the character, origin, structure and even the destiny of the universe (cf. Van Huyssteen 1998:47). In light of this notion, all cosmological reflection has a distinct interdisciplinary character. It is argued by Van Huyssteen (1998:47) that cosmology as a discipline seems to have 'subtle but very important implications for theology and philosophy'. This is because of the vagueness as to what the actual limits of cosmology as a discipline are. Theology and cosmology, as intellectual disciplines, are in essence both interdisciplinary in nature, and therefore they both share in a mutual quest for a more comprehensive understanding of the origin, meaning and destiny of the universe (cf. Van Huyssteen 1998:47).

Conflict between these two disciplines occurs when one or both parties overstep the boundaries of their own discipline and make assertions that overlap with claims made by the other (Johnson 2014:7). This is often the case when it comes to theories of evolution and theology. Christian fundamentalists hold a literal interpretation of Genesis, as if it renders an historical account of creation. Consequently, advocates of intelligent design or creation science judge evolution to be completely contradictory to the revealed word of God in scripture. In light of this, all scientific discoveries are explained otherwise and no other approaches to reading the biblical texts are considered. Alternatively, contemporary biblical scholarship reveals how the Genesis creation account can be read in accordance with its genre as a religious mythic narrative (Johnson 2014:7). The intent of the Genesis creation story is then to demonstrate that the one God who led the Israelites out of slavery is the universal Creator of all that exists. Following this perspective, the purpose of the Bible is to communicate not scientific facts but religious truths. In abiding by a literal reading of the text, the fundamentalist method of interpretation rejects this approach, thereby setting up a solid conflict with science. Johnson (2014:8) points to an alternative form of fundamentalism that seeks to defeat religion with the evolutionary theory. Advocates of this perspective hold that a Creator acting as described by religious fundamentalists does not exist, as evolutionary theories explain the design of the natural world by natural biological mechanisms. The fundamentalism of this approach involves taking natural explanations as the final and only word on all reality.

Science and theology may simply ignore and avoid each other in order to avoid conflict, but would that be a satisfactory stance? Johnson (2014:9), as well as others (e.g. Du Toit 2013; Ottati 2014; Van Huyssteen 1998; 2006), argues that in order to be plausible to any generation, Christian theology must express itself in ways consistent with the understanding of the world available at the time. It is essential for theology, considering the integrity it seeks to teach and live by, to take account of how the world created by God actually works, according to the best of current human knowledge. Therefore, a dialogue between theology 
and the natural sciences is crucial (cf. Johnson 2014:9). Both disciplines deal with the same one world even if it is in different ways. A dialogue offers a framework in which science and theology can accept their differences but also approach each other with respect and in the process be enriched by each other. A dynamic interchange in which both science and theology are open to insights of the other is necessary in order for institutions of science and theology to contribute to building up human culture rather than fragmenting it (cf. Johnson 2014:10).

This article opts for the relationship of dialogue between theology and the sciences. The conviction is that both theology and science hold important truths about the natural world. Science is concerned with the world as a structured system operating according to natural laws as causes (cf. Johnson 2014:10). Theology deals with the same world as related to God. Both disciplines shed light onto the order and beauty of the universe, and cherishing a dialogue between them can have fruitful results.

\section{Evolution as a harmonious way of creating (God's continued care for creation)}

Buitendag (2012:3) refers to Aristotle's urge to live and think in this cosmos, as well as his discerning between potentiality and actuality. The essence of anything is thus its potential to change. God's action in the world continues even though the world itself is already established (cf. Pannenberg 1993:11). Peters (1993:11), following Pannenberg, asserts that closely connected to the origin of creation is the conservation of creation, while the continued existence of the world is sustained by God's continued care for it. Creation does not remain what it was at its point of origin: 'It changes. It develops. New forms appear. New things happen. There is a sense in which one can say that creatio ex nihilo is complimented by creatio continua ... , continuing creation' (cf. Peters 1993:11). The notion of the faithfulness of God combines the ideas of conservation and governance with that of contingent creation (Peters 1993:12). This perspective indicates theologically that God is not static and that the created order is by no means made up of eternally fixed forms. The faithfulness of the creating God continues to conserve the existence of this world.

At this stage this study enquires whether this is not what is expected of a loving and graceful God - to quote part of a poem by Lord Tennyson where he describes God as follows (Tennyson 1965):

That God, which ever lives and loves

One God, one law, one element,

And one far-off divine event,

To which the whole creation moves (p. 28)

The theory of the evolution of life traces a unique biological phenomenon on one cosmic body, Earth. Planet Earth, however, does not stand alone, as it forms part of a solar system, which is part of the Milky Way Galaxy, which is part of a neighbourhood of galaxies, which form a section of the expanding universe (cf. Johnson 2014:111). Earthly life has a 3.5 billion year-long story, which is nestled in the 10 billion years of cosmic development that preceded it. This highlights the continuity and discontinuity of life on Earth with the rest of the universe. Johnson (2014:111) mentions that in recent times philosophers of science '... call upon the wider frameworks of cosmology and astronomy, themselves exploding with new discoveries, to arrive at a deeper grasp of evolution's significance'. According to contemporary scientific consensus, the universe originated about 13.7 billion years ago in a primordial explosion called the 'Big Bang' (cf. Johnson 2014:111; Van Huyssteen 1998:50). The universe, however, has continued to expand ever since that explosive moment. Edwin Hubble, in 1929, examined the 'red shift' of light from distant nebulae and formulated what is known today as Hubble's Law: ' ... the velocity of recession of a nebulae is proportional to its distance from us' (cf. Van Huyssteen 1998:50). It was this discovery by Hubble that led to the dating of the origin of the cosmos. Johnson (2014) points to the fascinating notion that even in that early phase of the Big Bang, the rate of cosmic expansion was calibrated 'just right': if it was:

$[T]$ oo high, $[$ then $]$... matter energy would have flown apart and thinned out so fast that no structures could have formed; too low, and the universe would have collapsed on itself. (pp. 111-113)

The conditions for life as it is known today were set up by an extraordinary degree of precision or 'fine tuning' in the properties of matter-energy, basic structures and laws of the cosmos. By placing the origin of species within the greater framework of the history of the universe, an illuminating light is casted in specific ways on life on Earth (cf. Johnson 2014:113).

Evolutionary biology, over time, demonstrates that the emergence of life has followed no predetermined blueprint; it is rather shot through with surprise. This is evident in genetic mutations caused by the sun's ultraviolet rays or exposure to chemicals that cause variations in the structure and behaviour of living organisms. As is evident in their rate of reproduction and survival, natural selection favours the ones that adapt best to their environments. And this process of a hundred thousand variables, breakthroughs and dead ends goes on and on (Johnson 2014:116). Johnson (2014) concludes her discussion with the following remark:

Taken together, scientific understandings of the indeterminism of physical systems at the quantum level, the unpredictability of chaotic systems at macro level, and the long-term random emergence of new forms through the evolutionary process itself undermined the idea that there is a detailed, unfolding plan according to which the world was designed and now operates. Rather, the stuff of the world has an innate creativity in virtue of which the new continuously emerges through the interplay of law and chance. (p. 117)

Taking Darwin into account within the bigger framework of the history of the universe as known today, it becomes illuminative that biological life is a tremendously special phenomenon. At the same time it is clear that the evolution of 
biological life is continuously at work with forces within cosmic time and space. Life on Earth arises in harmony with those dynamics present throughout the universe (Johnson 2014:117).

Creation can be defined as a 'cosmic ecology' (Ottati 2013:184). Ottati explains that this cosmic ecology is a formed and dynamic ensemble, an intricate vast system, a set of ordering. Human beings interact with a world of patterns, processes and structures. Objects, others, realities and situations are known and experienced by humans within an articulated environment. Therefore, 'world' refers to something very different than mere chaos or randomness. Following this line of thought, the image of God as Creator conveys and forms these experiences and ideas by maintaining that God forms, arranges and orders the 'worldas-a-whole' (cf. Ottati 2013:184).

\section{Ecological responsibility: Compulsory ethics for wisdom}

If one starts to explore human ecological responsibility in light of the current study, I think it would be wise to use Ottati's (2013:196) concept of the creation as a vast cosmic ecology as a starting point. Expressing the word 'ecology' in this way is, in Ottati's (2013:196) opinion, to stretch it beyond its more common and sterner meanings in the contexts of evolutionary biology on Earth. If one takes seriously the emphasis that terms such as 'ecosystem' and 'ecology' place on common webs, dynamic interactions, energy transfers and the like, as well as the stunning enlargement of our modern picture of cosmos, then the blatant anthropocentrism of Luther's notion of all creation-as-a-house explicitly built for human beings is avoided. ${ }^{6}$

In Ottati's (2013:200) opinion, the image of creation as a cosmic ecology helps to shape and express a pious notion of 'the distinctive role of humans'. The vast cosmos is clearly not centred in humans, or even in the particular solar system in which the Earth is located. Still, human beings have a special worth and position. We are stewards or 'distinctively equipped participants', and our recognition of this fact stimulates senses of both possibility and responsibility within us (Ottati 2013:200). We humans may use our significant powers of understanding and intervention in a way that reflects our awareness of the worth of both human beings and of the bigger jumble of interdependent interrelationships on which we and all other creatures depend. Our persistent failure to do so is, in fact, a distinctively human irresponsibility (cf. Ottati 2013:201).

For years now the stereotype was held that evolution consists of barely more than brutal competition between individuals (Johnson 2014:117). More recently the field of ecological science gave rise to a more subtle assessment that emphasises the interdependence of species in local habitats.

6.0ttati (2013:195) comments that Luther's image of creation-as-a-house-for-humans is too anthropocentric, and it is also too invested in a dichotomy between humans and the rest of nature.
Stevens (2013:3) refers to Darwin's (1859) description of the complex relations between organisms and stresses the fact that the environment is of utmost importance for the evolution of different types of species. Different organisms inhabit different worlds because they live in different sensory environments and are bound by the properties of their sensory organs, even though they might live in the same place at the same time. Sensory ecology highlights that because of different sensory systems in different creatures, any change in their environment can have an influence on behaviour and evolution (cf. Stevens 2013:3-4). Within different ecosystems every individual species is superbly adapted by evolutionary processes to interact with others in its locality (Johnson 2014:118). All organisms interact with the environment (Dodds 2009:40). This means that the environment is very sensitive and can be influenced by all kinds of species, especially by the behaviour of human beings.

The random behaviour in systems that creates chaos must also be taken into consideration in all forms of ecology. This emphasises the sensitivity of ecological systems even more. In defining ecological chaos, Sherrat and Wilkinson (2009:137) mention that elements of disorder, 'boundness' and sensitivity to initial conditions play an important role; they employ the following definition: 'a trajectory is chaotic if it is bounded in magnitude, is neither periodic nor approaches a periodic state, and is sensitive to initial conditions'. Therefore, it is the sensitivity to initial conditions that provides a key clue to chaotic dynamics (Sherrat \& Wilkinson 2009:137). Bearing all this in mind, one has to ask the question of how our ecological responsibility can be best articulated in light of the wisdom tradition.

The notion of human responsibility as a result of thankfulness or gratitude is a prominent theme in wisdom literature. Ecclesiastes (2:24; 3:13; 5:17-19; 9:7-9), for example, repeatedly argues that everything we receive is a gift from God. Human dependence upon God is emphasised. Therefore, ecological responsibility is not a matter of earning God's favour. However, this was the argument in the traditional view of wisdom and the concept of retribution. Ecological responsibility is a spontaneous act of gratitude. According to Brueggemann (2008:236), Torah obedience as well as its counterpoint in wisdom is constant. Brueggemann's (2008:236) argument is based on the sapiential conclusion that can be traced from Proverbs 3:7-8 through Job 28:28 and finally to Ecclesiastes 12:13. The matter of obedience, as evident in the wisdom literature, is not mere blind conformity. It is a serious engagement with an ultimately mysterious creator, which the Mosaic prophet tradition finds in the covenant and the wisdom teachers find in creation (cf. Brueggemann 2008:236). In the words of Brueggemann (2008:236): 'It is clear, of course, that specificity of covenant and the wonder of creation attest together to the God who will be obeyed'. Once this notion of obedience as an act of gratitude towards God is acknowledged, ecological responsibility becomes a natural part of human life. 
In the discussion on wisdom literature and world order, it has become clear that there is interaction and dialogue between creator and created and that it forms the axis of wisdom traditions (cf. Dell 2010:67).

Humans are part of a complex web of life, of which the need to sustain the world that they inhabit is the key. God is both the creator and sustainer of all life. Humans, however, have a major role to fulfil in sustaining the world and enabling all its processes to continue. These processes are all open to constant change. It is clear from the speeches of God in Job, for example, that all of creation should not be seen as subordinate to human beings.

\section{Concluding remarks}

The focus of this study was the ecological responsibility that arises when the creation is viewed in the wisdom literature with an evolutionary perspective. It was an interdisciplinary study combining science, theology and ecology. Scientific perspectives pointed to how all living things, through a powerful, unscripted evolutionary process that has lasted hundreds of millions of years, came into being, grew into their beautiful, complex forms and eventually fit into their diverse ecological niches. Theological perspectives informed us on how all living creatures are in the work of the spirit of God, who vivifies the community of creation from which humans have also emerged. Ecologically, this community of living things is now under immense threat because of human action.

A commitment to ecological wholeness is our human responsibility. We should seek to move beyond identifying ecological themes in creation theology towards identifying with Earth and the Earth community in their struggle for ecojustice (cf. Habel 2011:11). That is our responsibility. Ingall (2000:24) believes the Torah's perspective suggests that people have to attempt deliberately to live with the constraints caused by order. Habel (2011:134) agrees by showing that the Old Testament texts sometimes testify that when order is opposed, the result is an Earth filled with chaos and destruction. Wisdom lies in the acceptance of boundaries but also the acceptance of change and uncertainties. The ecological theme is found in various texts in the Old Testament, especially in the wisdom literature. These texts show interdependence between humans and other living creatures, human beings and the Earth, and human beings and God. Order is presented as wisdom. There is a clear link between ecology and order. By respecting this order and maintaining it, by living in harmony with the rest of creation, one assures for oneself and the rest of the creation a peaceful existence.

The question remains whether we have a responsibility towards conserving the environment. This seems to be a nonquestion. Conserving the environment is also a spiritual issue that needs to be addressed not only by churches and theologians but by everyone who is still alive, dependent and therefore also responsible for the environment. We should be able to willingly say yes, we are willing to live with a green conscience, attempting to guide the evolving creation in a positive direction with positive contributions, respecting the harmony of creation - a creation of an innovative and unpredictable God who created the world to be able to adapt.

\section{Acknowledgements Competing interests}

The authors declare that they have no financial or personal relationships that may have inappropriately influenced them in writing this article.

\section{Authors' contributions}

A.G-F. and B.S. contributed equally to the research and writing of this article.

\section{References}

Arnold, B.T., 2009, Genesis. New Cambridge Bible Commentary, Cambridge University Press, New York.

Barr, J., 1993, Biblical faith and natural theology. The Gifford lectures for 1991 delivered in the University of Edinburgh, Clarendon Paperbacks, Oxford.

Brown, W.P., 1999, Cosmos and ethos: The genesis of moral imagination in the Bible, Eerdmans, Grand Rapids, MI.

Brueggemann, W., 1982, Genesis: Interpretation: A Bible commentary for teaching and preaching, Westminster John Knox Press, Louisville, KY.

Brueggemann, W., 2008, Old Testament Theology: An Introduction, Library of Biblical theology, Abingdon Press, Nashville, TN.

Buitendag, J., 2012, 'Die noodsaaklikheid van habitat in ons definisie van menswees: Op soek na 'n eko-teologiese verstaan van menslike lewe', HTS Teologiese Studies/ Theological Studies 68(1), Art. \#1283, 8 pages. https://doi.org/10.4102/hts. v68i1.1283

Caldicott, H., 2009, If you love this planet: A plan to save the earth, Norton, New York.

Darwin, C., 1859, On the origin of species by means of natural selection, or the preservation of favoured races in the struggle for life, John Murray, London.

Deane-Drummond, C., 2000, Creation through wisdom, T\&T Clark, Edinburgh.

Deane-Drummond, C., 2004, The ethics of nature, Blackwell, Oxford.

Deane-Drummond, C., 2006, Wonder and wisdom, Longman \& Todd, London, Darton.

Deane-Drummond, C., 2008, Eco-theology, Novalis, Toronto.

Dell, K.J., 2010, 'The significance of the wisdom tradition in the ecological debate', in D.G. Horrell, et al. (eds.), Ecological hermeneutics: Biblical, historical and theological perspectives, T\&T Clark, New York.

Dodds, W.K., 2009, Laws, theories, and patterns in ecology, University of California Press, Berkley, Los Angeles, CA.

Du Toit, C.W., 2013, 'A scientific defence of religion and the religious accommodation of science? Contextual challenges and paradoxes', Herv. Teol. Stud. [online] 69(1), 1-9, viewed 15 March 2018, from http://www.scielo.org.za/scielo.php?script=sci arttext\&pid=S0259-94222013000100021\&Ing=en\&nrm=iso. ISSN 2072-8050.

Edwards, D., 1999, A Trinitarian theology: The god of evolution, Paulist Press, Mahwah, NJ.

Fuentes, A., 2017, The creative spark: How imagination made humans exceptional, Dutton, New York.

Gottwald, N.K., 1985, The Hebrew Bible, a socio-literary introduction, Fortress Press, Minneapolis, MN.

Goudie, A., 2013, The human impact on the natural environment: Past, present and future, 7 th edn., Wiley-Blackwell, Chichester, UK.

Habel, N., 2003, 'The implications of god discovering wisdom in earth', in E. van Wolde (ed.), Job 28: Cognition in context, pp. 281-97, Brill, Leiden.

Habel, N., 2011, The birth, the curse and the greening of earth: An ecological reading of genesis 1-11 (Earth Bible Commentary), Sheffield Phoenix Press, Sheffield.

Haught, J.F., 2008, God after Darwin: A theology of evolution, 2nd edn., Westview Press, Philadelphia, PA.

Haught, J.F., 2010, Making sense of evolution: Darwin, god and the drama of life, Westminster John Knox Press, Louisville, KY.

Hermisson, H.J., 1968, Studien zur israelitischen Spruchweisheit, WMANT, 28, Neukirchen-Vluyn.

Ingall, C.K., 2000, 'The wisdom of creation: A Jewish perspective', The Way Supplement 97, 21-27.

Johnson, E.A., 2014, Ask the beasts: Darwin and the god of love, Bloomsbury Publishing PIc, London. 
Loader, J.A., 2014, Historical commentary on the Old Testament: Proverbs 1-9, Peeters Publishers, Leuven.

McKibben, B., 2005, The comforting Whirlwind: God, job, and the scale of creation, Cowley, Cambridge, MA.

Murphy, R.E., 1985, 'Wisdom and creation', Journal of Biblical Literature 104(1), 3-11. https://doi.org/10.2307/3260589

Oberholzer, J.P., 1989, 'Teologie as wetenskap: Aantekeninge van buite die sistematiese Teologie', HTS Teologiese Studies/Theological Studies 45(2), 438-441. https://doi.org/10.4102/hts.v45i2.2286

Ottati, D.F., 2013, Theology for liberal protestants: God the creator, Wm. B. Eerdmans Publishing Co, Grand Rapids, MI.

Pannenberg, W., 1993, Toward a theology of nature: Essays on science and faith, Westminster/John Knox Press, Louisville, KY.

Perdue, L.G., [1994] 2014, Wisdom and creation, Abingdon Press, Nashville, TN.

Peters, T. (ed.), 1989, 'Pannenberg on theology and natural sciences', in W. Pannenberg (ed.), Toward a theology of naure: Essays on science and faith, Westminster/John Knox Press, Louisville, KY.

Preuss, H.D., 1970, 'Erwägungen zum theologischen Ort alttestamentlicher Weisheitliteratur,' EvTh 30, 393-417.

Preuss, H.D., 1987, Einführung in die alttestamentliche Weisheitliteratur, (UrbanTaschbücher 383), Kohlhammer, Stuttgart.

Sherrat, T.N. \& Wilkinson, D.M., 2009, Big questions in ecology and evolution, Oxford University Press, New York.
Spangenberg, I.J.J., 2014, 'Die "vergroening" van die Christelike godsdiens: Charles Darwin, Pierre Teilhard de Chardin en Lloyd Geering', HTS Teologiese Studies/ Theological Studies 70(1), Art. \#2712, 9 pages. https://doi.org/10.4102/hts. v70i1.2712

Steiert, F.J., 1990, Die Weisheit Israels - ein Fremdkörper im Alten Testament? Eine Untersuchung zum Buch der Sprüche auf dêm Hintergrund der ägyptischen Weisheitslerhen, Freiburg et al. (eds.), (FThs 143).

Stevens, M., 2013, Sensory ecology, behaviour, and evolution, Oxford University Press, Oxford, UK.

Tennyson, A., 1965, In memoriam', in L.C. Birch (ed.), Nature and god, SCM Press, London. Van Heerden, J., 2014, Creation and evolution, AuthorHouse, Bloomington, IN.

Van Huyssteen, J.W., 1998, Duet or duel: Theology and science in a postmodern world, SCM Press Ltd., London.

Van Huyssteen, J.W., 2006, Alone in the world?, W/m B. Eerdmans Publishing Co., Grand Rapids, MI.

Van Selms, A., 1967, Genesis II, POT, Nijkerk.

Von Rad, G., 1965, Old Testament theology: Volume I: The theology of Israel's historical traditions, D.M.G. Stalker (transl.), Harper \& Row, New York.

Von Rad, G., 1972, Wisdom in Israel, 3rd edn., SCM Press, London.

Westermann, C., 1978, Blessing in the Bible and the life of the Church, Westminster, Philadelphia, PA.

Zimmerli, W., 1964, 'The place and the limit of the wisdom in the framework of the old testament theology', SSJT 17, 146-158. https://doi.org/10.1017/S0036930600005780 